Journal of Animal and Veterinary Advances 10 (17): 2297-2300, 2011

ISSN: $1680-5593$

(C) Medwell Journals, 2011

\title{
Attitudes of Turkish Veterinary Educators to Problem-Based Learning
}

\author{
${ }^{1}$ Sule Osmanagaoglu, ${ }^{2}$ Melek Kalkan, ${ }^{1}$ Berfin Melikoglu, ${ }^{3}$ Ayse Mentes Gurler, \\ ${ }^{4}$ Turel Ozkul and ${ }^{5}$ Ali Yigit \\ ${ }^{1}$ Department of Veterinary History and Deontology, Faculty of Veterinary Medicine, \\ ${ }^{2}$ Department of Educational Sciences, Faculty of Education, \\ Ondokuz Mayis University, 55139 Samsun, Turkey \\ ${ }^{3}$ Department of Veterinary History and Deontology, Faculty of Veterinary Medicine, \\ Harran University, 63200 Sanliurfa, Turkey \\ ${ }^{4}$ Department of Veterinary History and Deontology, Faculty of Veterinary Medicine, \\ Uludag University, 16059 Bursa, Turkey \\ ${ }^{5}$ Department of Veterinary History and Deontology, \\ Faculty of Veterinary Medicine, Selcuk University, 42003 Konya, Turkey
}

\begin{abstract}
The objective of this study was to determine the attitude of veterinary educators to problem-based learning and to examine influential parameters. In this study, veterinary educators from the Ankara, Uludag, Selcuk, Harran and Ondokuz Mayis Veterinary Schools were surveyed. Data were collected from 254 educators by a paper questionnaire. The participants showed intermediate level positive attitude to problem-based learning. In conclusion, it can be said that veterinary educators in Turkey are sensitive to problem-based learning at an intermediate level and that differences in influential factors do not affect the level of sensitivity significantly $(\mathrm{p}<0.05)$.
\end{abstract}

$\underline{\text { Key words: Problem-based learning, veterinary educators, veterinary medicine, attitude, intermediate, Turkey }}$

\section{INTRODUCTION}

Problem-Based Learning (PBL) generally refers to the whole set of different attitudes to education and learning. Although, the term does not define a specific education method, it identifies the active learning process of students when solving a problem (Summerlee, 1997). In the PBL method, the cases the students come across with starting from the 1 st day of implementation make them feel that they have faced a real problem and need to learn the required knowledge to solve it. Owing to the intriguing nature of the problem, the student acquires an internal motivation and experiences the process of self-directed learning. PBL requires the student to use a wealth of information sources (Bauer and Ogilvie, 1996; Dolmans et al., 2005).

PBL was 1st used in medical education curricula in the 1950s. Later in the 1960s, it was implemented at the Brown, McMaster and New Mexico Universities in the United States of America (USA) and at the Maastricht University in the Netherlands (Summerlee, 1997). In 1991, it was determined that $>100$ medical schools had incorporated PBL either partly or fully into their curricula.
It was observed that while certain faculties combined PBL with their traditional curricula, some other faculties used PBL in parallel with traditional education (Bauer and Ogilvie, 1996).

Various techniques are used in veterinary education all over the world (Edmondson, 2001; Pickrell et al., 2002; Powell and Steel, 2003; Davis, 2003). PBL has triggered a major, complex and widespread change in educational practice within higher education, particularly in professional education (Dolmans et al., 2005). PBL has been adopted in educational programs in a variety of disciplines including veterinary medicine (Bauer and Ogilvie, 1996; Lane, 2008; Newman, 2005).

Problem-based learning has been incorporated into the veterinary curricula of universities such as the University of Queensland in Australia (Rand and Baglioni Jr., 1997) and Colorado state, University College of Veterinary Medicine and Biomedical Sciences in the USA (Grauer et al., 2008). Previous studies on the use of PBL in veterinary education are available (Bauer and Ogilvie, 1996; Edmondson, 2001; Farnsworth, 1997; Schoenfeld-Tacher et al., 2005). Among Turkish veterinary schools, Uludag University, Faculty of

Corresponding Author: Sule Osmanagaoglu, Department of Veterinary History and Deontology, Faculty of Veterinary Medicine, Ondokuz Mayis University, 55139 Samsun, Turkey 
Veterinary Medicine was to incorporate into the curriculum, an educational programme similar to problem based learning. Since 2008, Ondokuz Mayis University, Faculty of Veterinary Medicine partly implements problem-based learning together with traditional education firstly.

In Turkey to the knowledge, a comprehensive scientific study on the attitudes of Turkish veterinary educators to PBL has not been performed before. This study was aimed at determining the attitude of veterinary educators to problem-based learning.

\section{MATERIALS AND METHODS}

The present study was conducted on educators appointed at the Ankara Veterinary School (AVS), Uludag Veterinary School(UVS), Selcuk Veterinary School (SVS), Harran Veterinary School (HVS) and Ondokuz Mayis Veterinary School (OMVS) (Fig. 1). The technique described by Krejcie and Morgan (1970) was used in the selection of the samples.

Accordingly, the sample size of the study was determined as 254 educators out of the total number of academic staff (467). Proportional stratified sampling was used to determine the number of samples needed for each school. The samples were selected using systematic random sampling and data were collected from personally interviewed 254 participants by a paper questionnaire.

A questionnaire ${ }^{a}$ was designed to determine the attitudes of the participants to PBL. The questionnaire was composed of 2 sections. Demographic information was collected in the 1st section. Seven items including independent variables such as gender, high school of graduation, academic title, schools of employment, administrative duties, term of employment and department of study were asked to all participants in the 1 st section.

An attitude set for problem-based learning which included 38 items in total was represented in the 2 nd section. A 5 point Likert scale was used for the 2 nd section. Cronbach's alpha $(\alpha=0.90)$ of the scale revealed a high degree of internal consistency. After pre-tested by

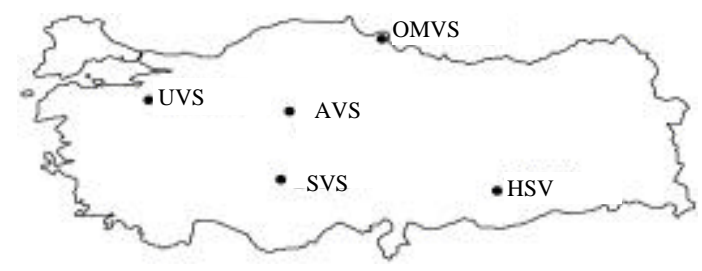

Fig. 1: The veterinary schools included in the survey ten educators, the survey was administered to the participants between June 2008 to February 2009 and data were collected via the questionnaire. Frequencies were used for demographic analyses. A mean score was calculated for PBL from all the 38 items.

Positive items were scored from 5 for strongly agree through 1 for strongly disagree with neutral in the middle of the scale scored as 3. SPSS Version 15.0 for windows was used and p values were calculated for all statistical analyses (those $<0.05$ were considered significant).

\section{RESULTS AND DISCUSSION}

The demographic values of the independent variables such as term of employment, age, gender, high school of graduation, academic title, schools of employment, administrative duties and department of study were determined in the study.

The arithmetic mean and standard deviation of the PBL attitude values of the sample were determined as 111.03 and 12.18 , respectively. For this purpose, standard deviation scores were both subtracted from and added to the arithmetic mean scores of PBL attitude levels, thereby enabling the definition of low, intermediate and high level groups. Accordingly, the group with scores of $\leq 98$ was defined as the low level group, the group with scores ranging from 99-123 was defined as the intermediate level group and the group with scores of $\geq 124$ was defined as the high level group. The PBL attitude levels of the individuals who participated in this study were determined to be intermediate.

The paper questionnaire was answered by 167 male and 87 female academicians. Of the participants, $27.6 \%$ held a professor title, $20.5 \%$ an associate professor title, $24.8 \%$ an assistant professor title and $14.2 \%$, a doctor of science degree. Detailed information on the independent variables of the participants are shown in Table 1 .

Although, the PBL attitude levels of the participants in the present study belonged to the intermediate level group, the demographic subgroups did not statistically differ from each other for PBL attitude.

Researches conducted on veterinary education in Turkey (Gul et al., 2008; Dincer, 1991; Gurler, 2007; Osmanagaoglu et al., 2009; Ozen et al., 2004a; Ozen and Ozen, 2006) and attitudes of Turkish veterinarians to different subjects (Ozen et al., 2004b, 2009; Ozen and Ozen, 2010; Yerlikaya et al., 2004) are available. However, a comprehensive scientific study on the attitudes of Turkish veterinary educators to problem based learning has not been conducted before. Therefore, it can be said that this is the 1st study on the attitude of veterinary 
Table 1: Distribution of independent variables and PBL attitude values (mean values) for groups of variables

\begin{tabular}{|c|c|c|c|c|}
\hline Variables & $\mathrm{N}$ & Percentge & PBL-AV & $p$-value \\
\hline \multicolumn{5}{|l|}{ Gender } \\
\hline Male & 167 & 65.7 & 111.03 & \multirow[t]{2}{*}{$>0.05$} \\
\hline Female & 87 & 34.3 & 111.05 & \\
\hline \multicolumn{5}{|l|}{ University } \\
\hline UVS & 70 & 27.6 & 112.32 & \multirow[t]{5}{*}{$>0.05$} \\
\hline OMVS & 61 & 24.0 & 111.75 & \\
\hline HVS & 24 & 9.4 & 105.58 & \\
\hline AVS & 48 & 18.9 & 113.37 & \\
\hline SVS & 51 & 20.1 & 108.78 & \\
\hline \multicolumn{5}{|l|}{ Academic title } \\
\hline Professor & 70 & 27.6 & 111.88 & \multirow[t]{6}{*}{$>0.05$} \\
\hline Associate professor & 52 & 20.5 & 111.75 & \\
\hline Assistant professor & 63 & 24.8 & 110.57 & \\
\hline $\mathrm{Dr}$ & 36 & 14.2 & 109.41 & \\
\hline Research assistant & 31 & 12.2 & 110.90 & \\
\hline Lecturer & 2 & 0.8 & 109.00 & \\
\hline \multicolumn{5}{|c|}{ Administrative duties } \\
\hline Yes & 37 & 14.6 & 113.91 & \multirow[t]{2}{*}{$>0.05$} \\
\hline No & 217 & 85.4 & 110.54 & \\
\hline \multicolumn{5}{|l|}{ Term of employment } \\
\hline$<1$ year & 18 & 7.1 & 111.33 & \multirow[t]{5}{*}{$>0.05$} \\
\hline $1-5$ years & 72 & 28.3 & 109.25 & \\
\hline $6-10$ years & 37 & 14.6 & 111.94 & \\
\hline $11-15$ years & 42 & 16.5 & 109.38 & \\
\hline$\geq 16$ y ears & 85 & 33.5 & 112.91 & \\
\hline \multicolumn{5}{|l|}{ Department } \\
\hline Basic sciences & 62 & 24.4 & 112.20 & \multirow[t]{3}{*}{$>0.05$} \\
\hline Clinical sciences & 137 & 53.9 & 111.31 & \\
\hline Zootechnics and anim & n 55 & 21.7 & 109.03 & \\
\hline
\end{tabular}

PBL-AV: PBL Attitude Values; p: significance (reflects the difference between the PBL sensitivity values given in the same column; $<0.05$ )

educators to PBL in Turkey. The results of this study demonstrated that Turkish veterinary educators show a positive (intermediate level) attitude to PBL. Similarly, Bauer and Ogilvie (1996) reported the belief of tutors in the benefit of PBL for students and pointed out to the fact that all tutors either agreed or strongly agreed with the continued use of PBL.

The accreditation procedure set up by the European Association of Establishments for Veterinary Education (EAEVE) emphasizes the significance of methods of acquiring, documenting and analysing scientific and technical data for education and includes the use of new techniques such as problem-based learning and interactive computer-assisted learning (Anonymous, 2009). Although, statistically insignificant the relatively high levels of attitude determined at the ASV and USV may be related to the outcome of accreditation efforts. As a matter of fact both of these schools have been accredited in Turkey.

Nonetheless, the attitudes not differing from each other significantly can be interpreted as the result of PBL not being implemented by the majority of Turkish veterinary schools and therefore, the display of an average attitude. Despite the absence of statistically significant differences within demographic variables, it was demonstrated that for academic title, professors, those appointed with administrative duties and staff with a term of employment $>16$ years displayed a slightly greater score for arithmetic means of PBL attitude levels. Contradictory to the common view, professors and staff with a term of employment $>16$ years are somewhat inclined to PBL rather than to traditional education. Similarly, it can be suggested that academic staff appointed with administrative duties show a higher tendency to incorporate PBL into the curriculum.

Rand and Baglioni Jr. (1997) reported a major increase in the number of students who strongly agreed that PBL enabled a better understanding of the subject and the ability to apply the principles of this method in new situations. Students shared the common view that the only disadvantage was the longer time required in comparison to traditional lecture-based classes.

In their study aimed at the assessment of the success of the integration of problem-based learning and other curricular changes throughout the implementation of a modified curriculum at the University of Tennessee, College of Veterinary Medicine in 1999, Howell et al. (2002) engaged both faculty facilitators and students unfamiliar to such modifications in programme assessment. The results of the preliminary assessment demonstrated a mostly positive reaction to problem-based learning.

Furthermore, Rand and Baglioni Jr. (1997) indicated that students' perceptions of the learning outcome were in favour of problem-based learning, compared to lecturebased education. Likewise, the educators who participated in the study showed a positive attitude to PBL. On the other hand in their study aimed at the comparison of traditional lecture-based learning and case based/problem-based learning. Grauer et al. (2008) suggested that the two teaching methods were of similar efficacy.

In the present study, it was determined that the arithmetic mean of the PBL attitude levels of academic staff working in the field of clinical sciences (53.9\%) was lower than the mean of the academic staff working in the field of basic sciences (24.4\%). However, Miller (1997) noted that clinics provide an experiential learning environment similar to that of $\mathrm{PBL}$.

\section{CONCLUSION}

In this study, it could be said that veterinary educators in Turkey are generally sensitive to PBL. From this point of view, it can be suggested that the academic staff of Faculties of Veterinary Medicine in Turkey show a positive attitude to the incorporation of PBL into the curriculum. 


\section{REFERENCES}

Anonymous, 2009. Annex I: Guidelines, requirements and main indicators for stage One (Ia) and stage two (Ib). EAEVE GA Hanover, http:/www.eaeve.org /fileadmin/downloads/sop/SOP_ANNEX1to2_Han over09.pdf.

Bauer, M. and G. Ogilvie, 1996. Incorporation of problem based learning into a third year veterinary curriculum. J. Vet. Med. Educ., 23: 43-46.

Davis, M.H., 2003. Outcome-based education. J. Vet. Med. Educ., 30: 258-263.

Dincer, F., 1991. A survey of veterinary education and administration in Turkey. Dtsch. Tierarztl Wochenschr, 98: 179-180.

Dolmans, D.H., W. de Grave, I.H. Wolfhagen and C.P. van der Vleuten, 2005. Problem-based learning: Future challenges for educational practice and research. Med. Educ., 39: 732-741.

Edmondson, K.M., 2001. Applying what we know about learning to veterinary education. J. Vet. Med. Educ., 28: 54-55.

Farnsworth, C.C., 1997. Measuring the effects of problembased learning on the development of veterinary students' clinical expertise. Acad. Med., 72: 552-554.

Grauer, G.F., S.D. Forrester, C. Shuman and M.W. Sanderson, 2008. Comparison of student performance after lecture-based and case-based/ problem-based teaching in a large group. J. Vet. Med. Educ., 35: 310-317.

Gul, R.T., T. Ozkul, A. Akcay and A. Ozen, 2008. Historical profile of gender in Turkish veterinary education. J. Vet. Med. Educ., 35: 305-309.

Gurler, A.M., 2007. Animal welfare education in Turkey. J. Vet. Med. Educ., 34: 633-638.

Howell, N.E., I.F. Lane, J.J. Brace and R.M. Shull, 2002. Integration of problem-based learning in a veterinary medical curriculum: First-year experiences with application-based learning exercises at the University of Tennessee College of Veterinary Medicine. J. Vet. Med. Educ., 29: 169-175.

Krejcie, R.V. and D.W. Morgan, 1970. Determining sample size for research activities. Educ. Psychol. Measur., 30: $607-610$.

Lane, E.A., 2008. Problem-based learning in veterinary education. J. Vet. Med. Educ., 35: 631-636.

Miller, C.W., 1997. Experiential learning in veterinary education. J. Vet. Med. Educ., 24: 48-51.
Newman, M.J., 2005. Problem Based Learning: An introduction and overview of the key features of the approach. J. Vet. Med. Educ., 32: 12-20.

Osmanagaoglu, S., M. Kalkan, A.M. Gurler and M.E. Sardogan, 2009. A study on determining the opinion of veterinarians on continuing education. Kafkas Univ. Vet. Fak. Derg., 15: 157-161.

Ozen, A., R. Kalin, H. Yerlikaya, I. Seker and B. Cetinkaya, 2004a. Evaluating the curriculum of the veterinary school of Firat University, Turkey, in terms of professional and technical skills. J. Vet. Med. Educ., 31: 281-288.

Ozen, A., R. Ozturk, A. Yasar, A. Armutak and R.T. Basagac et al., 2004b. An attitude of veterinary practitioners towards animal rights in Turkey. Vet. Med. Czech, 49: 298-304.

Ozen, R. and A. Ozen, 2006. Veterinary education in Turkey. J. Vet. Med. Educ., 33: 187-196.

Ozen, A., R. Ozen, A. Yasar, A. Armutak, S. Bayrak, A. Gezman and I. Seker, 2009. Attitudes of Turkish veterinary students and educators towards the moral status of animals and species rating. Kafkas Univ. Vet. Fak. Derg., 15: 111-118.

Ozen, R. and A. Ozen, 2010. Attitudes of Erciyes University students to the use of animals in research. Kafkas Univ. Vet. Fak. Derg., 16: 477-481.

Pickrell, J.A., J. Boyer, F.W. Oehme, V.L. Clegg and N. Sells, 2002. Group learning improves case analysis in veterinary medicine. J. Vet. Med. Educ., 29: 43-49.

Powell, V. and C.H. Steel, 2003. Search for the woolly mammoth: A case study in inquiry-based learning. J. Vet. Med. Educ., 30: 254-257.

Rand, J.S. and A.J. Baglioni Jr., 1997. Subject-based problem-based learning in the veterinary science course $t$ the University of Queensland. Aust. Vet. J., 75: $120-125$.

Schoenfeld-Tacher, R., J.M. Bright, S.L. McConnell, W.S. Marley and L.R. Kogan, 2005. Web-based technology: Its effects on small group problem-based learning interactions in a professional veterinary medical program. J. Vet. Med. Educ., 32: 86-92.

Summerlee, A.J.S., 1997. Making sense of problem-based learning. Proceedings of the International Education Symposium, (IES'97), Budapest, pp: 11-22.

Yerlikaya, H., A. Ozen, A. Yasar, A. Armutak and R. Ozturk et al., 2004. Survey of attitudes of Turkish veterinary students and educators about animal use in research. Vet. Med. Czech., 49: 413-420. 